\title{
Decline of Vasopressin Immunoreactivity and mRNA Levels in the Bed Nucleus of the Stria Terminalis Following Castration
}

\author{
Margaret A. Miller, ${ }^{1,2}$ Geert J. DeVries, ${ }^{5}$ Hussien A. Al-Shamma, ${ }^{5}$ and Daniel M. Dorsa ${ }^{1,2,3,4}$ \\ ${ }^{1}$ Geriatric Research, Education, and Clinical Center, Veterans Administration Medical Center, Seattle, Washington 98108 , \\ Departments of ${ }^{2}$ Psychiatry and Behavioral Sciences, ${ }^{3}$ Medicine, and 4 Pharmacology, University of Washington, Seattle, \\ Washington 98195 and ${ }^{5}$ Program of Neuroscience and Behavior and Department of Psychology, University of \\ Massachusetts, Amherst, Massachusetts 01003
}

\begin{abstract}
Vasopressinergic (VP) neurons in the bed nucleus of the stria terminalis (BNST) of the rat are regulated by gonadal steroids. Gonadectomy causes the projections of the BNST to lose their VP immunoreactivity gradually over a period lasting more than 2 months. Here we have compared the rate of decline of VP mRNA and VP immunoreactivity in the BNST of adult male rats following castration. In experiment 1, the peak number of VP-immunoreactive cells and the level of VP gene expression were compared in sham-operated controls and at 1, 3, or 8 weeks postcastration. The number of VP-immunoreactive cells was not decreased at 1 week postcastration but was significantly reduced $(p<0.0001)$ at 3 and 8 weeks postcastration. VP gene expression declined more rapidly, and both the total number of labeled cells ( $p$ $<0.0001)$ and the average number of grains per cell ( $p<$ 0.01 ) were significantly reduced by 1 week postcastration. No VP-expressing cells were detectable at 3 or 8 weeks. The difference in the rate of decline in the number of cells labeled by the two techniques following castration did not appear to be due to colchicine pretreatment. In experiment 2 , VP mRNA in the BNST was compared in sham-operated controls or at 1,3 , or $7 \mathrm{~d}$ postcastration. A significant decrease $(p<0.01)$ in the average number of grains per cell was detectable by just $1 \mathrm{~d}$ following castration, and the number of labeled cells was significantly reduced $(p<0.001)$ by $3 \mathrm{~d}$ postcastration. These results indicate that the capacity of BNST cells to synthesize VP responds more dynamically to changes in gonadal steroid levels than do levels of VP immunoreactivity. This difference may reflect the delay between VP gene expression and the processing of VP precursor molecules. Alternatively, gonadal steroids may modulate the release of VP from cells in the BNST.
\end{abstract}

Gonadal steroids influence brain physiology and behavior by targeting specific neuronal systems (McEwen and Parsons, 1982). Vasopressin (VP) cells in the bed nucleus of the stria terminalis

\footnotetext{
Received Nov. 22, 1991; revised Feb. 12, 1992; accepted Mar. 2, 1992.

We thank Cheryl Refsdal, Pamella Kolb, and Judith Brewer for their excellent technical support. This work was funded by NIH Grant NS20311 (D.M.D.), the Rescarch Service of the Department of Veterans Affairs (D.M.D.), and NSF Grant BNS 8809799 (G.J.D.)

Correspondence should be addressed to Dr. Margaret A. Miller, Department of Psychiatry and Behavioral Sciences RP.10, University of Washington, Seattle, WA 98195 .

Copyright (C) 1992 Society for Neuroscience $0270-6474 / 92 / 122881-07 \$ 05.00 / 0$
}

(BNST) appear to be a prime target of gonadal steroid actions. In rats, these neurons are sexually dimorphic. Male rats have more neurons in the BNST that express VP mRNA (Miller et al., 1989c) or can be stained immunocytochemically for VP(Van Leeuwen et al., 1985) than female rats. In addition, the VPimmunoreactive projections of these neurons to the septum are denser in males than in females (De Vries et al., 1981, 1983). Gonadal steroids appear to influence the development of these pathways in the early postnatal period (De Vries et al., 1983) and act to maintain the pathways in adulthood (De Vries et al., $1984,1985,1986)$. Castration of adult male rats results in the disappearance of VP-immunoreactive cells in the BNST (Van Leeuwen et al., 1985) and immunoreactive fibers in the septum (De Vries et al., 1984, 1985), although the time course is extremely slow. Approximately 8-12 weeks are needed following castration for the complete disappearance of VP-immunoreactive fibers in the septum (De Vries et al., 1984). While VPexpressing cells in the BNST also disappear following castration (Miller et al., 1989b), the time course of the effects of gonadal steroid removal on VP gene expression has yet to be determined. In this study, we have compared the decline over time of VP mRNA levels and VP immunoreactivity of cells in the BNST following castration.

\section{Materials and Methods}

Subjects and general protocol

Experiment I. Intact male Wistar rats (90 d old) were obtained from Charles River Labs (Wilmington, MA) and were maintained under a $12 \mathrm{hr}$ light $/ 12 \mathrm{hr}$ dark cycle. Food and water were available ad libitum. Animals were killed as sham-operated controls or at 1, 3, or 8 weeks postcastration. Sham-operated controls were killed 1 week postsurgery. All of the animals for immunocytochemistry and some of the shamoperated controls for in situ hybridization were treated with colchicine ( $35 \mu$ g, i.c.v.) $48 \mathrm{hr}$ prior to death. For immunocytochemistry, rats were perfused through the ascending aorta with $50 \mathrm{ml}$ of $0.9 \%$ saline, followed by $5 \%$ acrolein in $0.1 \mathrm{~m}$ phosphate-buffered saline (pH 7.2) for $5 \mathrm{~min}$ (about $300 \mathrm{ml}$ per animal). The brains were removed and sectioned at $50 \mu \mathrm{m}$ on a vibratomc. Sections were collected in $0.05 \mathrm{M}$ Tris- $\mathrm{HCl}$. For in situ hybridization, brains were removed following decapitation, frozen on dry ice, and sectioned at $20 \mu \mathrm{m}$ on a cryostat. Cryostat sections were thaw-mounted on RNase-free gelatin-coated slides and stored at $-70^{\circ} \mathrm{C}$ prior to being hybridized.

Experiment 2. Intact male Wistar rats $(90 \mathrm{~d}$ old) were obtained from Simonsen Laboratories (Gilroy, CA) and were maintained under a 12 hr light/12 hr dark cycle. Food and water were available ad libitum. Animals were killed as sham-operated controls or at 1,3 , or $7 \mathrm{~d}$ postcastration. Sham-operated controls were killed $1 \mathrm{~d}$ postsurgery. Brains were collected for in situ hybridization and were processed as outlined above. 


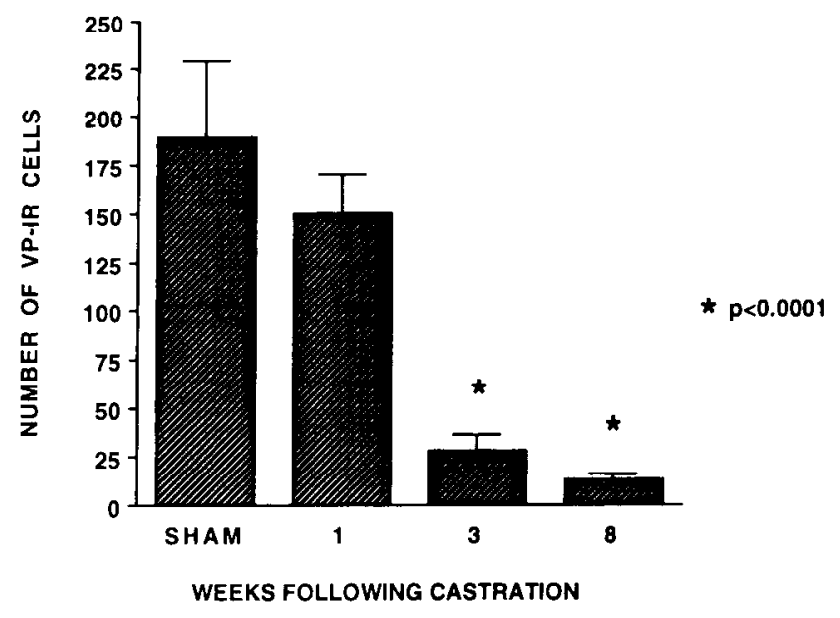

Figure 1. Total number of VP-immunoreactive neurons identified unilaterally in four atlas-matched sections through the BNST. The number of VP-immunoreactive cells is significantly decreased by 3 weeks postcastration. Data are presented as the mean \pm SEM.

\section{Immunocylochernistry}

Immunocytochemistry was performed as previously described (De Vries and Al-Shamma, 1990). Free-floating sections were treated with (1) $0.1 \%$ sodium borohydride followed by (2) $0.05 \mathrm{~m}$ Tris- $\mathrm{HCl}, \mathrm{pH} 7.6$ (Tris) and (3) $2 \%$ goat serum, $0.9 \% \mathrm{NaCl}$, and $0.5 \%$ Triton $\mathrm{X}-100$ in Tris (TrisTriton) for $15 \mathrm{~min}$. Sections were incubatcd overnight at $4^{\circ} \mathrm{C}$ in antiVP(ICN, Lisle, IL) diluted 1:2000 in Tris-Triton. Following incubation, sections were (1) rinsed in Tris-Triton for $15 \mathrm{~min}$, (2) treated for 45 min with goat anti-rabbit IgG serum (ICN) diluted 1:150 in Tris-Triton, (3) rinsed for $15 \mathrm{~min}$ in Tris-Triton, (4) treated for $45 \mathrm{~min}$ with rabbit peroxidase-antiperoxidase serum diluted 1:300 in Tris-Triton, and (5) rinsed for $15 \mathrm{~min}$ in Tris-Triton. These second and third antibody incubation steps were repeated, and sections were then rinsed in $0.9 \%$ $\mathrm{NaCl}$ in Tris (Tris- $\mathrm{NaCl}$ ) and reacted with $0.05 \% 3,3^{\prime}$-diaminobenzidine in Tris- $\mathrm{NaCl}$ with $0.01 \% \mathrm{H}_{2} \mathrm{O}_{2}$ for $20 \mathrm{~min}$. After being rinsed in Tris$\mathrm{NaCl}$, sections were mounted on slides, air dried, and coverslipped. Specificity of the antiserum was verified by (1) the absence of immunoreactive cells in brain sections from VP-deficient Brattleboro rats and (2) the absence of immunoreactive neurons in sections stained with antiserum that had been reacted with $50 \mu \mathrm{M}$ VP.

\section{In situ hybridization}

In situ hybridization procedures were the same as previously described (Miller et al., 1989a). Briefly, sections were postfixed in 4\% paraformaldehyde, treated with $0.25 \%$ acctic anhydride, dehydrated, delipidated, and air dried. A ${ }^{35}$ sulfur-labeled oligonucleotide probe was applied, and sections were coverslipped. The probe used was a 48-base oligonucleotide complementary to the mRNA encoding the last 16 amino acids of the glycopeptide portion of the VP precursor. The probe was $3^{\prime}$ endlabeled with terminal deoxynucleotidyl transferase, purified, heat denatured, and diluted to $2.5 \mathrm{pmol} / \mathrm{ml}$ in hybridization buffer [ $50 \%$ formamide, $10 \%$ dextran sulfate, $300 \mathrm{~mm} \mathrm{NaCl}, 10 \mathrm{~mm}$ Tris, $1 \mathrm{~mm}$ EDTA, $1 \times$ Denhardt's $(0.02 \%$ each BSA. Ficoll, polyvinylpyrollidone), $0.5 \mathrm{mg}$ / $\mathrm{ml}$ yeast tRNA, and $10 \mathrm{~mm}$ dithiothreitol] before use. Specific activities were estimated at $4400 \mathrm{Ci} / \mathrm{mmol}$ (experiment l) and $5700 \mathrm{Ci} / \mathrm{mmol}$ (experiment 2). A $45 \mu \mathrm{l}$ volume was applied to two brain sections per slide. After overnight incubation, coverslips were removed and sections were washed four times in $1 \times \mathrm{SSC}(150 \mathrm{~mm} \mathrm{NaCl}, 15 \mathrm{~mm} \mathrm{Na}$ citrate) for $15 \mathrm{~min}$ at $55^{\circ} \mathrm{C}$, followed by two $1 \mathrm{hr}$ room temperaturc washes in $1 \times$ SSC. Sections were dehydrated through a graded series of alcohols containing $300 \mathrm{~mm}$ ammonium acetate, dipped in Kodak NTB2 emulsion (Eastman Kodak, Rochester, NY; diluted 1:1 with $600 \mathrm{~mm}$ ammonium acetate), and exposed for $14 \mathrm{~d}$ (experiment 1) or $17 \mathrm{~d}$ (experiment 2). Emulsion was developed in D-19 diluted 1:1 with distilled water at $16^{\circ} \mathrm{C}$. Sections were counterstained with cresyl violet acetate and coverslipped. All samples from a single experiment were run in a single assay. In order to increase our ability to detect low levels of VP gene expression, the specific activity of the probe and the exposure time were increased in experiment 2.

\section{Quantification}

For immunocytochemistry, sections through the BNST of each animal were anatomically matched using the stereotaxic atlas of Konig and Klippel (1963). VP-immunoreactive cells were identified in bright-field and counted on the side of colchicine injection in four sections that corresponded to atlas levels $6790-6570$. The cells were counted independently by two researchers that were blind to the treatment groups. Data for each group is presented as the mean \pm SEM of the total number of cells observed. Groups were compared using a one-way analysis of variance followed by a Sheffe $F$ test. The criterion for significance was set at $p<0.05$

For in situ hybridization, sections through the BNST of each animal were also matched using the Konig and Klippel atlas (levels 6790-6570). One section at each of the four atlas levels was read blindly by a single experimenter. Labeled cells were identified in dark-field, and the presence of an underlying neuron was verified using high-magnification bright-field microscopy. Cells were considered to be labeled if the signalto-noise ratio of the cell was 5 or greater. The total number of cells found unilaterally in the four sections was determined for each animal. The number of grains per cell for up to 10 randomly selected cells per section at each of the four levels (i.e., up to 40 cells/animal) was measured by an automated image analysis system and averaged for each animal. The grain-counting system consisted of a DATA Cube IVG128 video acquisition board attached to an IBM AT computer. Video images were obtained by a Dage model 65 camera attached to an Olympus microscope (Olympus, New Hyde Park, NY) equipped with a $40 \times$ objective and dark-field condenser (see Chowen et al., 1991, for a detailed description of the grain counting methodology). Data are presented as the mean \pm SEM. For each experiment, a one-way analysis of variance followed by a Sheffé test was used to assess differences between the groups. Criterion for significance was set at $p<0.05$.

\section{Results}

\section{Experiment I}

As can be seen in Figure 1, the total number of VP-immunoreactive cells found unilaterally in the four sections through the BNST declines following castration. Although animals castrated for 1 week do not differ significantly from sham-operated controls ( 1 week: $149.5 \pm 20, n=6$; control: $189.4 \pm 39.5, n=$ $6)$, cell number is significantly decreased $(p<0.0001)$ in animals castrated for 3 weeks $(28.5 \pm 7.2, n=5)$. By 8 weeks postcastration $(n=6)$, an average of only $13.3 \pm 2.8$ stained cells were observed. Figure 2 shows low-power bright-field photomicrographs of VP-immunoreactive neurons in the BNST of a representative control animal $(A)$ and animals castrated for $1(B)$, $3(C)$, or $8(D)$ weeks.

The number of cells expressing VP mRNA in the BNST declines more rapidly following castration than the number of VPimmunoreactive cells. As shown in Figure 3, the total number of labeled cells found unilaterally in the four atlas-matched sections is significantly reduced by 1 week postcastration (98.6 \pm 8 vs. $9.0 \pm 5.1 ; n-5$ /group). The remaining cells exhibited a reduced labeling intensity, with $57.2 \pm 3.0$ versus $31.8 \pm 3.0$ grains/cell for controls and 1 week castrates, respectively (Fig. 4). No VP-expressing cells were detectable at 3 or 8 weeks postcastration in this experiment ( $n=5$ /group). By the established criteria, pretreatment of sham-operated controls $(n=5)$ with colchicine did not significantly influence the number of labeled cells or the labeling intensity compared to untreated sham-operated controls.

\section{Experiment 2}

As can be seen in Figure 5, the VP mRNA levels in the BNST are significantly decreased by just $1 \mathrm{~d}$ following castration. The average number of grains per cell declined over time from 77.4 $\pm 3.1(\mathrm{sham}, n=5)$ to $65.5 \pm 1.7(1 \mathrm{~d}, n=6), 50.5 \pm 2.1(3$ $\mathrm{d}, n=6)$, and $40.0 \pm 1.0(7 \mathrm{~d}, n=6)$. The average total number 
A

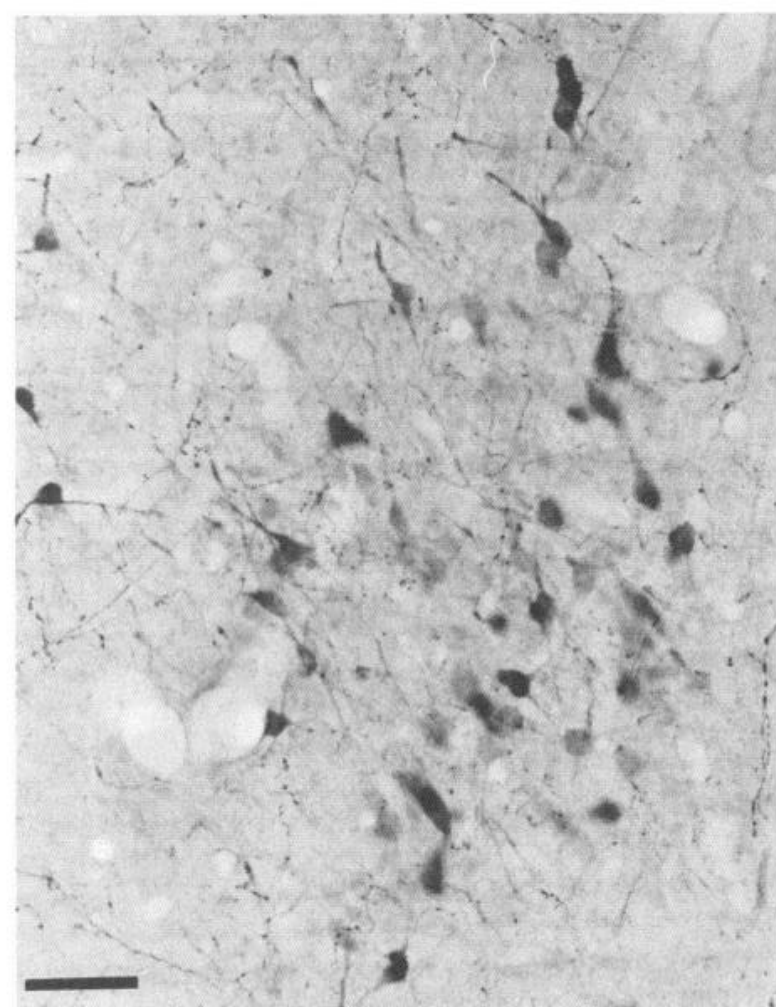

C

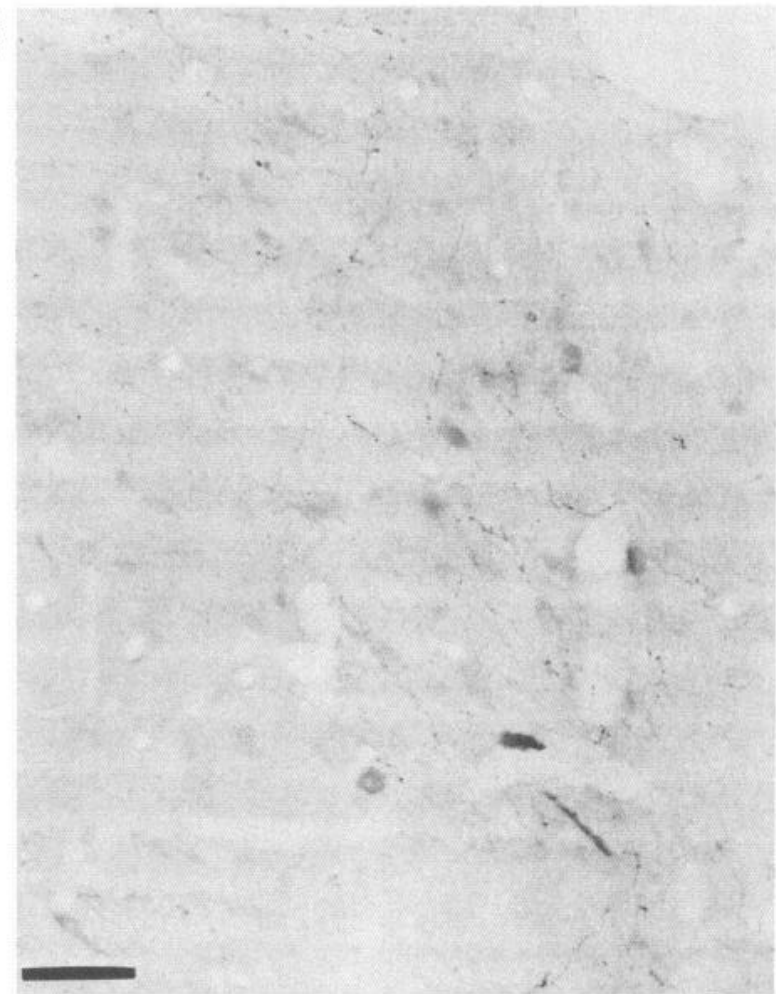

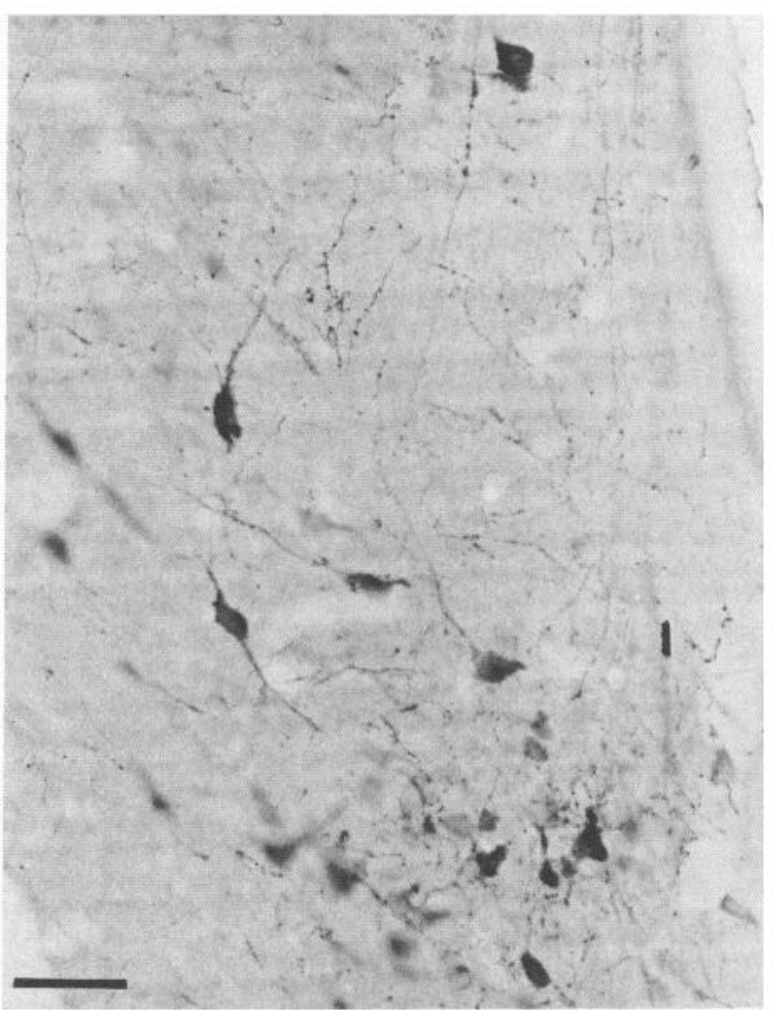

B

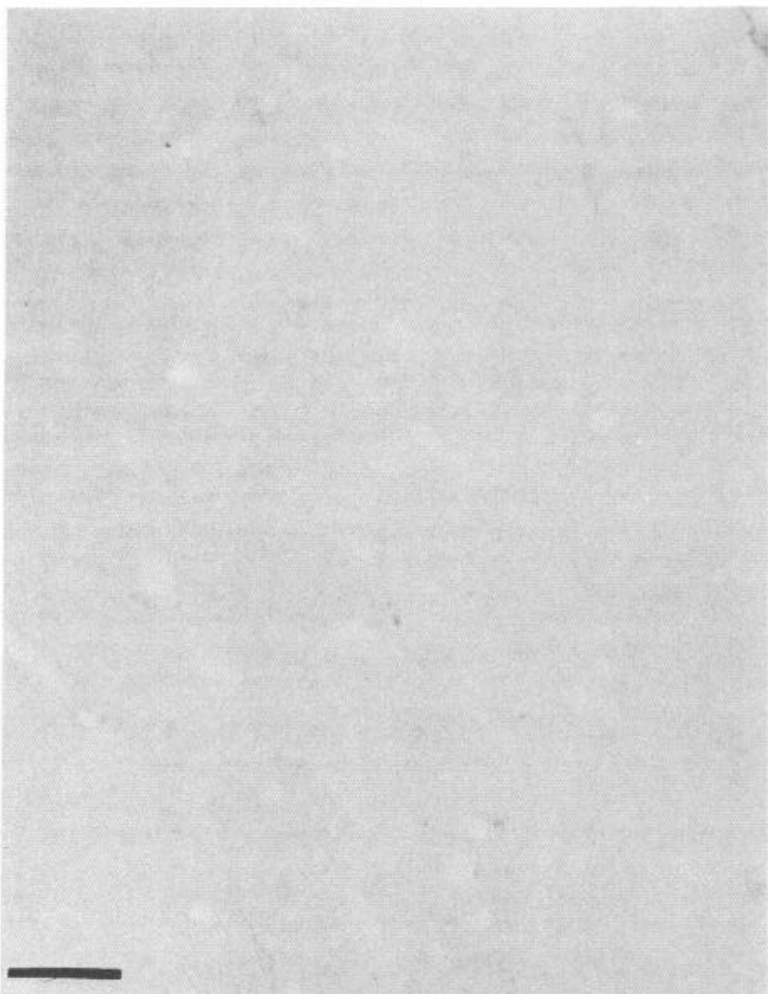

D

Figure 2. Low-power bright-field photomicrographs of VP-immunoreactive neurons in the BNST (level 6670) of a representative sham-operated control animal $(A)$ and animals castrated for $1(B), 3(C)$, and 8 weeks $(D)$. Scale bars, $40 \mu \mathrm{m}$ 


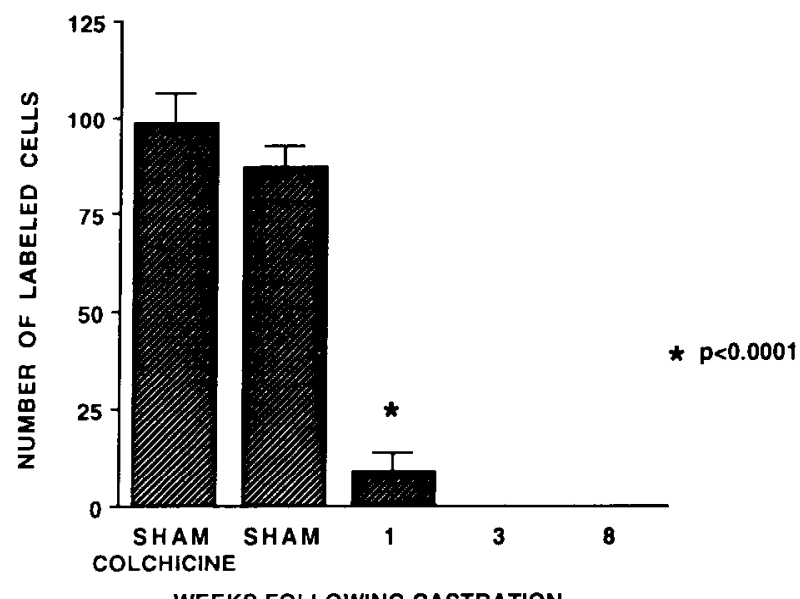

WEEKS FOLLOWING CASTRATION

Figure 3. Total number of neurons expressing VP mRNA identified unilaterally in four atlas-matched sections through the BNST. The number of labeled cells is significantly reduced by 1 week postcastration. Pretreatment with colchicine does not significantly affect the number of VP-expressing neurons. Data are presented as the mean \pm SEM.

of labeled cells in the four atlas-matched sections is significantly reduced by $3 \mathrm{~d}$ following castration and further reduced by $7 \mathrm{~d}$ postcastration (Fig. 6). Signal-to-noise ratios of labeled cells averaged 20 in sham-operated controls and 18,16 , and 12 in rats castrated for 1,3 , or $7 \mathrm{~d}$, respectively. Low-power darkfield photomicrographs of hybridized sections through the BNST of representative animals are shown in Figure 7.

\section{Discussion}

In this article, we report that VP mRNA levels in the BNST respond more dynamically to steroid hormone removal than does VP immunoreactivity. We found that VP gene expression in the BNST was dramatically reduced by 1 weck postcastration whereas the number of VP-immunoreactive neurons was not significantly reduced until 3 weeks postcastration. In a second experiment, we observed that VP mRNA levels were significantly decreased by just $1 \mathrm{~d}$ following castration. The average

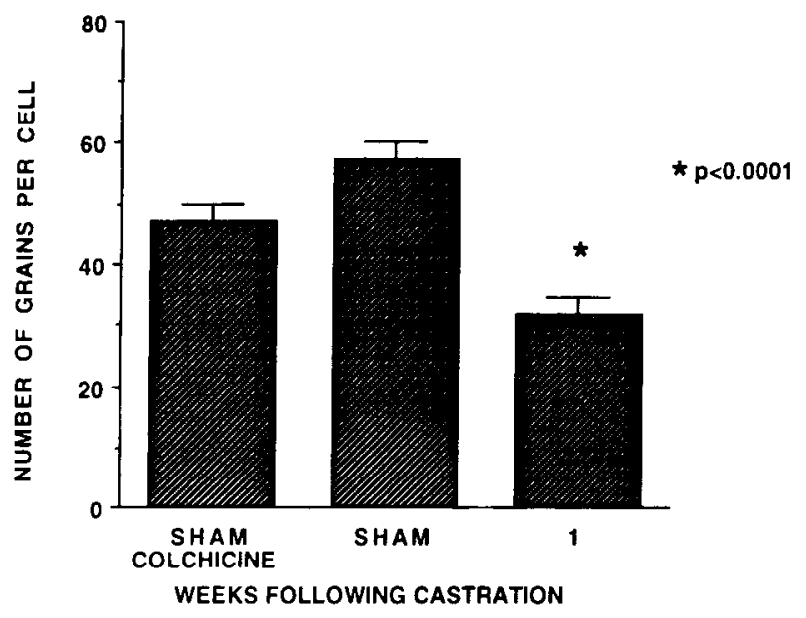

Figure 4. Average number of grains per cell expressed by VP neurons in BNST. At 1 week postcastration, cells had significantly fewer grains/ cell than did sham-operated controls. Pretreatment of sham-operated controls with colchicine reduced labeling intensity compared to untreated sham-operated controls. Data are presented as the mean \pm SEM.

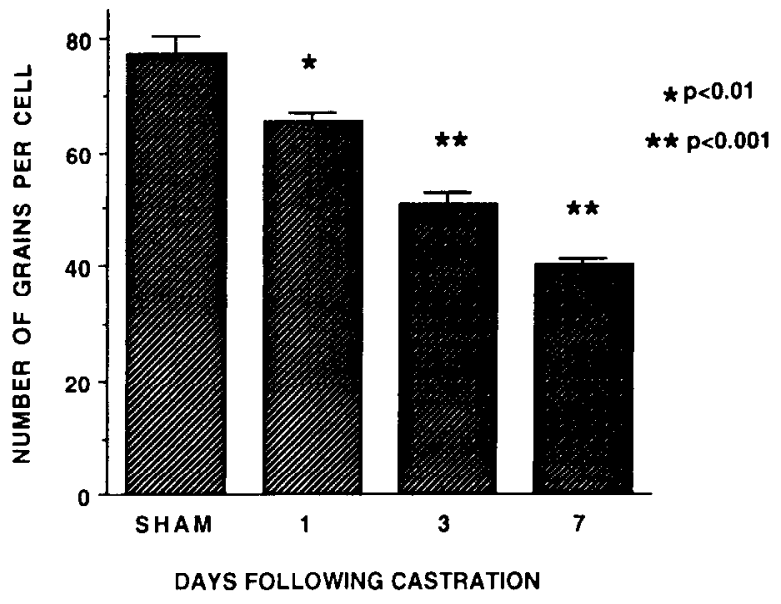

Figure 5. Average number of grains per cell expressed by VP neurons at 1,3 , and $7 \mathrm{~d}$ postcastration. Labeling intensity is significantly reduced by $1 \mathrm{~d}$ postcastration. Data are presented as the mean \pm SEM.

labeling intensity was decreased by $15 \%, 35 \%$, and $48 \%$ at 1,3 , and $7 \mathrm{~d}$, respectively. At $3 \mathrm{~d}$ postcastration, a significant decline could also be detected in the number of cells expressing VP mRNA. This suggests that mRNA levels may be a more sensitive index than immunoreactivity for assessing the acute effects of steroid hormones on VP neurons in the BNST.

The slower postcastration decline of the VP immunoreactivity than of VP mRNA could be due to colchicine treatment, which was only given to animals used for immunocytochemistry. Although early reports suggested that colchicine treatment did not influence gene expression (Gee and Roberts, 1983; Wolfson et al., 1985), recent studies have indicated that biosynthesis of several transmitter systems is indeed affected by colchicine and the direction of this effect is dependent on both the particular transmitter and the site of synthesis (Cortes et al., 1990). The differential decline of VP immunoreactivity and VP mRNA levels in the BNST could occur if colchicine treatment stimulated VP synthesis and increased peptide content. We assessed the effects of colchicine on VP synthesis by comparing mRNA levels in sham-operated controls with and without colchicine.

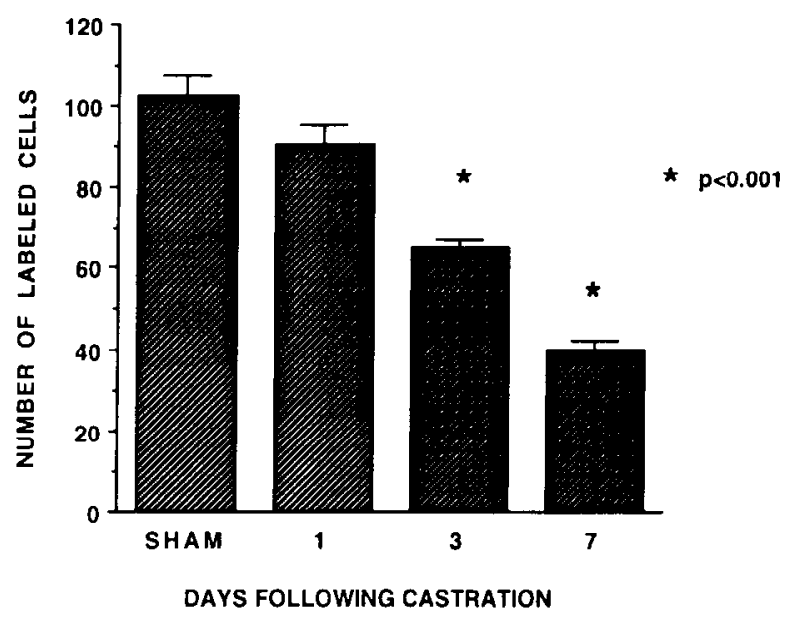

Figure 6. Total number of labeled cells identified unilaterally in four atlas-matched sections through the BNST at 1,3 , and $7 \mathrm{~d}$ postcastration. The number of labeled cells is significantly reduced by $3 \mathrm{~d}$ following castration. Data are presented as the mean \pm SEM. 

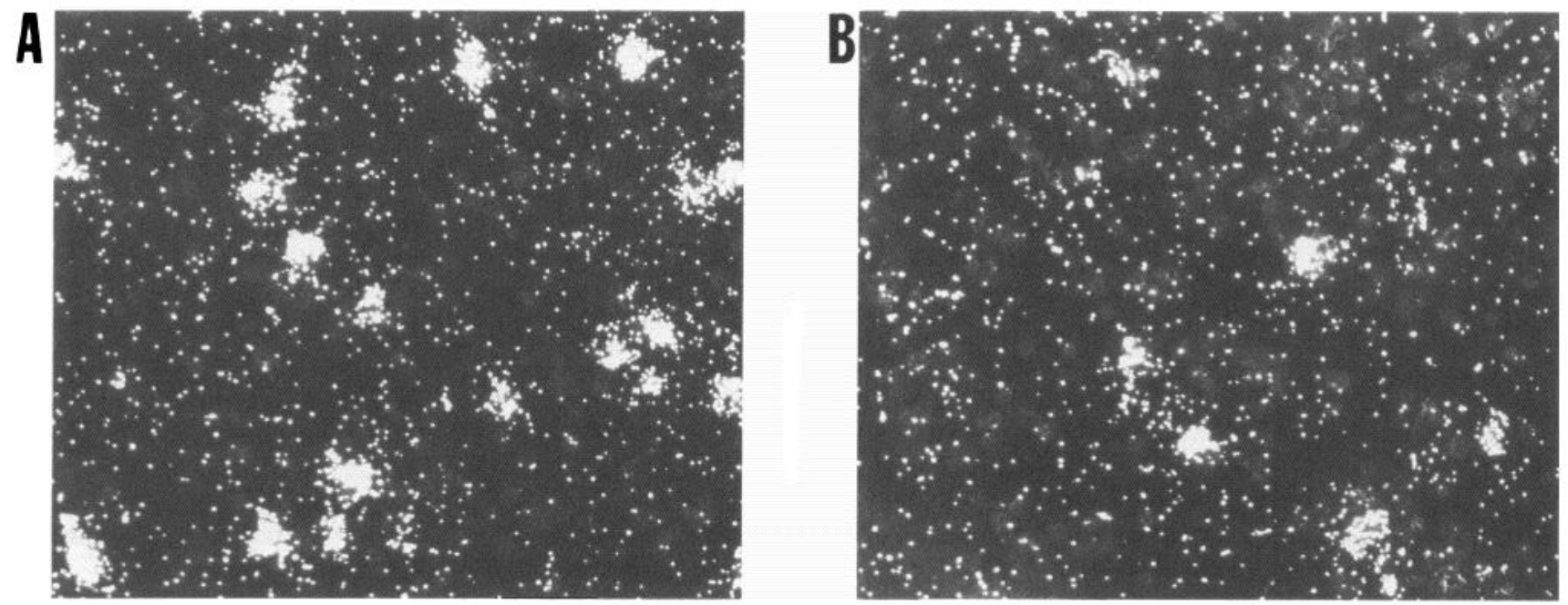

Figure 7. Low-power dark-field photomicrographs of sections (atlas level 6670) hybridized for VP mRNA from a representative sham-operated control $(A)$ and an animal castrated for $7 \mathrm{~d}(B)$.

We found that although there was a tendency for reduced labeling intensity, treatment of sham-operated controls with colchicine did not significantly influence VP gene expression in the BNST by our criteria. Unless this tendency would be reversed in castrated rats, these findings suggest that the difference in the rate of decline of VP mRNA and immunoreactivity cannot be attributed to colchicine pretreatment.

VP immunoreactivity could be dependent on several factors including peptide synthesis, release, and degradation. The difference between the decline of VP mRNA levels and the more gradual decline of VP immunoreactivity in the BNST may reflect steroid effects on any of these parameters. Peptide synthesis and processing in the intact animal has been shown to require on the order of several hours (Eipper et al., 1987). This would suggest that factors other than the time necessary for translation and processing contribute to the difference in postcastration decline of VP immunoreactivity and VP mRNA. However, gonadal steroids may also regulate the processing of peptide precursors and alter this expected time frame. Steroid hormones have been shown to influence the processing of other peptides by influencing the activity or levels of processing enzymes. In the paraventricular nucleus, glucocorticoids regulate the expression of peptidyl-glycine $\alpha$-amidating monooxygenase (Grino et al., 1990), an enzyme involved in the processing of prepropressophysin. In addition, processing of the prohormone for gonadotropin-releasing hormone is modified by castration (Culler et al., 1988). The strong staining of cell bodies observed at 1 week postcastration indicates that VP is accumulating in the somata after colchicine treatment. Whether this represents de novo synthesis or posttranslational processing to immunocytochemically accessible peptide cannot be determined. The rate of processing of the VP precursor may also be reduced following castration. The availability of antibodies directed against spacer peptides of the prepropressophysin molecule (Verbalis et al., 1991) might make it possible to determine whether the rate of processing is reduced following castration.

In addition to potential changes in synthesis and processing, VP transport may be reduced following castration. Recent studies in the magnocellular system have reported that the transport of VP is linked to the rate of synthesis (Roberts et al., 1991). If
VP transport in extrahypothalamic cells is also linked to synthesis, then castration-induced decreases in peptide synthesis would be expected to result in decreases in transport as well. Therefore, it is conceivable that castration-dependent differences in production, processing, and transport might all contribute to the delayed decline of VP immunoreactivity following castration.

Alternatively, VP release from neurons in the BNST may be very low in the basal state such that previously translated peptide may remain stored within the cell and its processes for prolonged periods of time. Early estimates of VP disappearance from the neural lobe of the rat indicated a half-life of approximately $19 \mathrm{~d}$ (Burford and Pickering, 1973). Whether VP in extrahypothalamic sites disappears with a similar time course is not known. A slow release is a potential explanation for the gradual (3 month) disappearance of VP immunoreactivity from the terminals (De Vries et al., 1984).

Castration may reduce VP release even further. There is at least indirect evidence that VP release in the ventral septum (presumably from neurons in the BNST) is reduced following castration. In intact rats, injections of pyrogens stimulate VP release in the septum (Cooper et al., 1979), which is linked to suppression of fever (Kasting, 1989). Long-term castrated rats show prolonged fever following challenge with a pyrogen, which may be related to lowered VP release (Pittman et al., 1988). No study has as yet evaluated the effects of short-term castration on central VP release.

Steroids could affect peptide synthesis and release by several different mechanisms. Since VP content of BNST projections appears to depend on the aromatization of testosterone to estradiol (De Vries et al., 1986), and VP-immunoreactive cells within the BNST can also be immunostained for estrogen receptors (Axelson and Van Leeuwen, 1990), steroids could influence synthesis and release by acting directly on the VP cells. As yet, no estrogen response element has been identified in the VP gene. However, steroids can influence VP cells in a variety of ways. In other neuronal systems, for example, steroids can rapidly modulate the excitability of cells via changes in ionic conductance (Moss and Dudley, 1984; Nabekura et al., 1986; Minami et al., 1990). They can modify synaptic inputs by in- 
fluencing receptor density (I Iammer, 1985; De Kloet et al., 1986; O'Connor et al., 1988) as well as transmitter biosynthesis (Blum et al., 1987; Argente et al., 1990; Chowen et al., 1990). They can even influence the number of axodendritic synapses in adult animals (Miyakawa and Arai, 1987). Theoretically, these steroid effects could independently influence the different processes involved in VP synthesis and release by BNST neurons, which could explain a discrepancy in postcastration decline in VP mRNA and peptide levels.

Slow changes in neuropeptide content following gonadectomy are also seen in other neuronal systems. Although we did not quantify this, we noted that VP neurons in the medial amygdala (MA) showed a similar gradual decline in immunoreactivity as VP neurons in the BNST. VP cells in the MA and BNST are similar in other respects as well, including size and morphology (Caffe and Van Leeuwen, 1983; Van Leeuwen and Caffe, 1983), presence of estrogen receptors (Axelson and Van Lccuwcn, 1990), sex differences in projections (De Vries and Al-Shamma, 1990), and response to castration (De Vries et al., 1986). One might therefore predict that the rate of postcastration decline in VP mRNA levels in MA cells and BNST cells is also similar.

A gradual decline following castration has also been reported for the neuropeptide content of cholecystokinin (CCK) and substance $P$ cells and fibers in the medial preoptic nucleus (MPN), BNST, and MA of the rat and hamster (Swann and Newman, 1987; Malsbury and Nance, 1989). In male rats, CCK cells in the MA, BNST, and preoptic area show a postcastration decrease in CCK content that lasts for more than 2 weeks and is restored by testosterone treatment (Simerly and Swanson, 1987). The cells in the MA and BNST may be the source of CCK fibers in the MPN, which gradually lose their immunoreactivity over a period of 8 weeks following castration (Malsbury and Nance, 1989). Although there are no data availablc on the postcastration decline in CCK mRNA levels in males, CCK mRNA levels in females vary across the estrous cycle (Simerly et al., 1988), which suggests that CCK cells may also respond within a day to changes in gonadal steroid levels in males. Conversely, the rate of change in VP mRNA we have observed after castration in males would allow for changes in VP mRNA across the estrous cycle as well.

In conclusion, we have observed that the number of VPexpressing cells in the BNST declines more rapidly following castration than the number of VP-immunoreactive neurons. This difference in time course cannot be attributed to colchicine pretreatment and may reflect the delay between VP gene expression and the production and processing of VP precursor molecules.

\section{References}

Argente J, Chowen-Breed JA, Steiner RA, Clifton DK (1990) Somatostatin messenger RNA in hypothalamic neurons is increased by testosterone through activation of androgen receptors and not by aromatization to estradiol. Neuroendocrinology 52:342-349.

Axelson JF, Van Leeuwen FW (1990) Differential localization of estrogen receptors in various vasopressin synthesizing nuclei of the rat brain. J Neuroendocrinol 2:209-216.

Blum M, McEwen BS, Roberts JL (1987) Transcriptional analysis of tyrosine hydroxylase gene expression in the tuberoinfundibular dopaminergic neurons of the rat arcuate nucleus after estrogen treatment. J Biol Chem 262:817-821.

Burford GD, Pickering BT (1973) Intra-axonal transport and turnover of neurophysins in the rat. Biochem J 136:1047-1052.

Caffe AR, Van Leeuwen FW (1983) Vasopressin-immunoreactive cells in the dorsomedial hypothalamic region, medial amygdaloid nucleus and locus coeruleus of the rat. Cell Tissue Res 233:23-33.
Chowen JA, Argente J, Vician L, Clifton DK, Steiner RA (1990) Proopiomelanocortin messenger RNA in hypothalamic neurons is increased by testosterone through aromatization to estradiol. Neuroendocrinology 52:581-588.

Chowen JA, Steiner RA, Clifton DK (1991) Semiquantitative analysis of cellular somatostatin mRNA levels by in situ hybridization histochemistry. Methods Neurosci 5:137-158.

Cooper KE, Kasting NW, Lederis K, Veale WL (1979) Evidence supporting a role for endogenous vasopressin in natural suppression of fever in the sheep. J Physiol (Lond) 295:33-45.

Cortes R, Ceccatelli S, Schalling M, Hokfelt T (1990) Differential effects of intracerebroventricular colchicine administration on the expression of mRNAs for neuropeptides and neurotransmitter enzymes, with special emphasis on galanin: an in situ hybridization study. Synapse 6:369-391.

Culler MD, Valenca MM, Merchenthaler I, Flerko B, Negro-Vilar A (1988) Orchidectomy induces temporal and regional changes in the processing of the luteinizing hormone-releasing hormone prohormone in the rat brain. Endocrinology 122:1968-1976.

De Kloet ER, Voorhuis DAM, Boschma Y, Elands J (1986) Estradiol modulates density of putative 'oxytocin receptors' in discrete rat brain regions. Neuroendocrinology 44:415-421.

De Vries GJ, Al-Shamma HA (1990) Sex differences in hormonal responses of vasopressin pathways in the rat brain. J Neurobiol 21 : 686-693.

De Vries GJ, Buijs RM, Swaab DR (1981) Ontogeny of the vasopressinergic neurons of the suprachiasmatic nucleus and their extrahypothalamic projections in the rat brain - presence of a sex difference in the lateral septum. Brain Res 218:67-78.

De Vries GJ, Best W, Sluitter AA (1983) The influence of androgens on the development of a sex difference in the vasopressinergic innervation of the rat lateral septum. Dev Brain Res 8:377-380.

De Vries GJ, Buijs RM, Sluitter AA (1984) Gonadal hormone actions on the morphology of the vasopressinergic innervation of the adult rat brain. Brain Res 298:141-145.

De Vries GJ, Buijs RM, Van Leeuwen FW, Caffe AR, Swaab DF (1985) The vasopressinergic innervation of the brain in normal and castrated rats. J Comp Neurol 233:236-254.

De Vries GJ, Duetz W, Buijs RM, Van Heerikhuize J, Vreeburg JTM (1986) Effects of androgens and estrogens on the vasopressin and oxytocin innervation of the adult rat brain. Brain Res 399:296-302.

Eipper BA, May V, Cullen EI, Sato SM, Murthy ASN, Mains RE (1987) Cotranslational and posttranslational processing in the production of bioactive peptides. In: The third generation of progress (Meltzer HY, ed), pp 385-400. New York: Raven.

Gee CE, Roberts JL (1983) In situ hybridization histochemistry: a technique for the study of gene expression in single cells. DNA 2: 157-163.

Grino M, Guillaume V, Boudouresque F, Conte-Devoix B, Maltese JY, Oliver C (1990) Glucocorticoids regulate peptidyl-glycine $\alpha$-amidating monoxygenase gene expression in the rat hypothalamic paraventricular nucleus. Mol Endocrinol 4:1613-1619.

Hammer RP Jr (1985) The sex hormone-dependent development of opiate receptors in the rat medial preoptic area. Brain Res 360:6574.

Kasting NW (1989) Criteria for establishing a physiological role for brain peptides. A case in point: the role of vasopressin in thermoregulation during fever and antipyresis. Brain Res Rev 14:143-153.

Konig JFR, Klippel RA (1963) The rat brain: a stereotaxic atlas of the forebrain and lower parts of the brain stem. New York: Kreiger.

Malsbury CW, Nance DM (1989) CCK and substance P fiber density within the medial preoptic nucleus: sex differences and castration effects. Soc Neurosci Abstr 14:669.

McEwen BS, Parsons B (1982) Gonadal steroid action on the brain: neurochemistry and neuropharmacology. Annu Rev Pharmacol Toxicol 22:555-598.

Miller MA, Urban JH, Dorsa DM (1989a) Quantification of mRNA in discrete cell groups of brain by in situ hybridization histochemistry. Methods Neurosci 1:164-182.

Miller MA, Urban JH, Dorsa DM (1989b) Steroid dependency of vasopressin neurons in the bed nucleus of the stria terminalis by in situ hybridization. Endocrinology 125:2335-2340.

Miller MA, Vician L, Clifton DK, Dorsa DM (1989c) Sex differences in vasopressin neurons in the bed nucleus of the stria terminalis by in situ hybridization. Peptides 10:615-619. 
Minami T, Oomura Y, Nabekura J, Fukada A (1990) 17 Beta-estradiol depolarization of hypothalamic neurons is mediated by cyclic AMP. Brain Res 519:301-307.

Miyakawa M, Arai $Y$ (1987) Synaptic plasticity to estrogen in the lateral septum of adult male and female rats. Brain Res 436:184-188.

Moss RL, Dudley CA (1984) Molecular aspects of the interaction between estrogen and the membrane excitability of hypothalamic nerve cells. Prog Brain Res 61:3-22.

Nabekura J, Oomura Y, Minami T, Mizuno Y, Fukada A (1986) Mechanisms of the rapid effect of 17 beta-estradiol on medial amygdala neurons. Science 233:226-228.

O'Connor LH, Nock B, McEwen BS (1988) Regional specificity of gamma-aminobutyric acid receptor regulation by estradiol. Neuroendocrinology 47:473-481.

Pittman QJ, Malkinson TJ, Kasting NW, Vcalc WL (1988) Enhanced fever following castration: possible involvement of brain arginine vasopressin. Am J Physiol 254:R513-R517.

Roberts MM, Robinson AG, Hoffman GE, Fitzsimmons MD (1991) Vasopressin transport regulation is coupled to the synthesis rate. Neuroendocrinology 53:416-422.

Schmale H, Heinsohn S, Richter D (1983) Structural organization of the rat gene for the arginine vasopressin-neurophysin precursor. EMBO J 2:763-767.
Simerly RB, Swanson LW (1987) Castration reversibly alters levels of cholecystokinin immunoreactivity within cells of three interconnected sexually dimorphic forebrain nuclei in the rat. Proc Natl Acad Sci USA 84:2087-2091.

Simerly RB, Young BJ, Swanson LW (1988) Regulation of preprocholecystokinin mRNA in the medial amygdala by estrogen: an in situ hybridization study in the rat. Soc Neurosci Abstr 14:17.

Swann JM, Newman SW (1987) Effect of castration and testosterone treatment on substance $P$ levels within the vomernasal pathway of the male golden hamster. Soc Neurosci Abstr 13:1576.

Van Leeuwen FW, Caffe AR (1983) Vasopressin-immunoreactive cell bodies in the bed nucleus of the stria terminalis of the rat. Cell Tissue Res 228:525-534.

Van Leeuwen FW, Caffe AR, De Vries GJ (1985) Vasopressin cells in the bed nucleus of the stria terminalis of the rat: sex differences and the influence of androgens. Brain Res 325:391-394.

Verbalis JG, Hoffman GE, Rosenbaum LC, Nilaver G, Loh YP (1991) Generation and characterization of an antiserum directed against neurohypophyseal prohormones. J Neuroendocrinol 3:267-272.

Wolfson B, Manning RW, Davis LG, Arentzen R, Baldino F (1985) Co-localization of corticotropin releasing factor and vasopressin mRNA in neurons after adrenalectomy. Nature 315:59-61. 